Sains Malaysiana 47(3)(2018): 563-569

http://dx.doi.org/10.17576/jsm-2018-4703-17

\title{
Multi-walled Carbon Nanotubes/Woven Kenaf Fabric-Reinforced Epoxy Laminated Composites
}

(Komposit Laminat Epoksi Diperkuat Tiub Nano Karbon Berbilang Dinding/Fabrik Tenunan Kenaf)

\author{
NURUl HidAYAH ISMAIL, MOHD HAFIZI BIN MOHAMAD \& MARIATTI JAAFAR*
}

\begin{abstract}
This study was carried out to investigate the effect of adding 1 vol\% of multi-walled carbon nanotubes (MWCNT) into woven kenaflepoxy laminated composites on their flexural properties and to compare between two techniques used to incorporate MWCNT into the composite which are spraying and solution techniques. Furthermore, the effect of MWCNT addition in woven glass/woven kenaflepoxy hybrid composites at the same filler concentration on the flexural properties were also investigated. All the laminated composites with and without MWCNT were fabricated using vacuum bagging method. The flexural properties of the composite samples with and without MWCNT were evaluated by applying threepoint bending test. The results were supported by morphological observation. It was found that the addition of MWCNT using both spraying and solution techniques reduced the flexural strength and flexural modulus of MWCNT/woven kenaf/ epoxy composites, with obvious reduction trend was shown by former technique. The morphological observation of the composites fracture surface showed that delamination failure occurred in MWCNT/woven kenaflepoxy laminated composite prepared by spraying technique. Further investigation on hybrid composites showed that MWCNT/woven glass/woven kenaflepoxy laminated hybrid composites exhibited significant improvement in the flexural properties.
\end{abstract}

Keywords: Flexural properties; hybrid composite; multi-walled carbon nanotubes; woven glass; woven kenaf

\section{ABSTRAK}

Kajian ini dijalankan untuk mengkaji kesan penambahan 1 vol\% tiub nano karbon berbilang dinding (MWCNT) ke dalam fabrik tenunan kenaflepoksi komposit laminat ke atas sifat lenturannya dan untuk membandingkan antara dua teknik yang digunakan untuk memasukkan MWCNT ke dalam komposit tersebut iaitu teknik semburan dan teknik larutan. Tambahan lagi, kesan penambahan MWCNT ke dalam komposit hibrid tenunan kaca/tenunan kenaflepoksi pada kepekatan pengisi yang sama juga dikaji. Semua komposit laminat dengan MWCNT dan tanpa MWCNT telah direka menggunakan kaedah beg vakum. Sifat lenturan sampel komposit dengan dan tanpa MWCNT dinilai dengan menggunakan ujian lenturan tiga titik. Keputusan itu disokong oleh pemerhatian morfologi. Didapati bahawa penambahan MWCNT menggunakan kedua-dua teknik semburan dan teknik larutan telah mengurangkan kekuatan lenturan dan modulus lenturan MWCNT/tenunan kenafl epoksi dengan trend pengurangan yang jelas ditunjukkan oleh teknik semburan. Pemerhatian morfologi pada permukaan patah komposit mendedahkan bahawa kegagalan delaminasi berlaku dalam komposit laminat MWCNT/tenunan kenaf/ epoksi yang disediakan dengan kaedah semburan. Kajian lanjut pada komposit hibrid menunjukkan bahawa komposit hibrid laminat MWCNT/tenunan kacaltenunan kenaflepoksi mempamerkan peningkatan yang ketara dalam sifat lenturan.

Kata kunci: Komposit hibrid; sifat lenturan; tenunan kaca; tenunan kenaf; tiub nano karbon berbilang dinding

\section{INTRODUCTION}

Kenaf fibre is one of the most popular natural fibres that have increasingly been used in polymer matrix composites (PMCs) to replace synthetic fibres due to the fact that kenaf has low density, yielding relatively light weight composite with high specific mechanical properties as well as easy handling and processing (Dittenber \& Gangarao 2012). The applications of kenaf as reinforcement in PMCs are growing in many sectors such as furniture, construction, automobiles and packing due to their low cost, low weight and less damage compared to synthetic fibres (Krishna \& Kanny 2016). However, though the other advantages of kenaf such as biodegradable, renewable resources, nonabrasive and non-hazardous make kenaf fibre as suitable comparator to synthetic fibre in many ecological characteristics, several drawbacks such as a low strength, variability in quality, high moisture absorption, limited processing temperature, and a lesser durability and incompatibility between fibres and polymer matrices limit their application (Dittenber \& Gangarao 2012; Maslinda et al. 2017).

Many efforts have been done to improve the performance of structural natural fibre composite (Li et al. 2007; Yusriah et al. 2010). Hybridization is one of the effective ways apart from chemical treatments which are often complicated and difficult to control due to the complexity of the chemical compositions of natural fibres. Hybridization can be done between natural fibre and synthetic fibres or natural fibres with fillers (Yusriah 
et al. 2010). It has been suggested that through proper combination of reinforcements, hybrid composites that offer a wider range of physical and mechanical properties that cannot be obtained by a single reinforcement can be produced, thus subsequently extend their potential applications.

In this study, multi-walled carbon nanotube (MWCNT) was added into woven kenaf/epoxy laminated composite to produce hybrid composite with improved flexural properties. A comparative study was made between the two techniques (spraying and solution) employed to incorporate MWCNT into woven kenaf/epoxy laminated composites. Besides that, the effect of hybridizing kenaf and glass fibre is also reported in this study and the effect of adding MWCNT into this hybrid composite on the flexural properties was investigated. The results of flexural test were supported by density measurement and morphological observation.

\section{MATERIALS AND METHODS}

\section{MATERIALS}

Woven kenaf fabric (KF) with linear density of $276 \mathrm{gm}^{-2}$ was supplied by Urich Technology. Plain weave E-typed glass fibre (GF) with a linear density of $600 \mathrm{gm}^{-2}$ was purchased from Changshu Dongyu Insulated Compound Materials, Co., Ltd., China. The D.E.N.431 epoxy novolac resin and Polyetheramine D230 (supplied by Penchem Industries Sdn. Bhd.) were used as matrix and curing agent, respectively. The MWCNT used was synthesized via catalytic chemical vapour deposition (CCVD) process by a group of researchers from School of Chemical Engineering, Universiti Sains Malaysia, Penang. The MWCNT was purchased from USAINS Holding Berhad. The filler with $80 \%$ purity has average diameter of $10 \mathrm{~nm}$ and average length of $1-5 \mu \mathrm{m}$.

MWCNT utilized in this research was known to have hydrophobic properties. Therefore, throughout this research the MWCNT was dispersed in deionized water with the aid of dispersing agent. The dispersing agent chosen in this research was Chinese black ink. The brand of the ink was Kin's Ink Liquid No. 29, Quan Pai Trade Mark. This black ink was manufactured by Shanghai factory China and supplied by Thian Li Trading. The stabilizers existed in this ink acted as MWCNT dispersing agent. Resin which existed in the ink helps to bind the MWCNT onto the fabric (Dalina 2017).

\section{METHODS}

\section{FABRICATION OF WOVEN KENAF/EPOXY} LAMINATED COMPOSITE

Control samples of 2-ply, 3-ply and 4-ply KF/epoxy laminated composites were prepared using kenaf woven mats with similar dimensions. The fabrics were first weighed to determine the amount of epoxy matrix needed.
The amount of epoxy matrix was fixed at 70 vol\%. The predetermined epoxy resin was mixed with curing agent at a ratio of 100:32 epoxy:curing agent. Subsequently, an adequate amount of epoxy layer was then spread on the release film surface. One ply of KF was laid on top of the epoxy layer. The roller was used to roll over on the top of the fabric to ensure that the fabric was evenly wet by the epoxy resin. The procedure was repeated for the second layer of KF. After spreading the final layer of epoxy resin, a perforated film was placed on top of the layer followed by breather material and vacuum bag. The sample was then consolidated by vacuum bagging with pressure vacuum of $600 \mathrm{mmHg}$ for about $40 \mathrm{~min}$. The consolidated $\mathrm{KF} / \mathrm{epoxy}$ composite was left for overnight curing. The sample was then cured at $80^{\circ} \mathrm{C}$ for $2 \mathrm{~h}$ and post-cured at $125^{\circ} \mathrm{C}$ for 3 $\mathrm{h}$. The same procedures were repeated in the fabrication of 3-ply and 4-ply KF/epoxy laminated composites. These control samples were denoted as $2 \mathrm{KF}, 3 \mathrm{KF}$ and $4 \mathrm{KF}$ for 2-ply, 3-ply and 4-ply KF/epoxy laminated composites, respectively. The hand lay-up and vacuum bagging procedure performed in the fabrication of 3-ply KF/epoxy laminated composites is showed in Figure 1.

\section{FABRICATION OF MWCNT/WOVEN KENAF/EPOXY} LAMINATED COMPOSITE BY SPRAYING TECHNIQUE

MWCNT were coated on woven kenaf mat by spraying MWCNT suspension on one surface of the woven mat prior to the hand lay-up and vacuum bagging process. The MWCNT suspension was prepared by adding the predetermined mass of MWCNT (1.0 vol. \%) into $60 \mathrm{~mL}$ of deionized water and mixed with 5.6 vol. $\%$ of Chinese black ink. The suspension was ultrasonicated in a water bath for $30 \mathrm{~min}$. The prepared suspension was then sprayed onto each piece of KF fabric of the same dimensions. The fabrics were left to dry at room temperature for about $4 \mathrm{~h}$ to allow evaporation of deionized water. The dried fabrics were stacked up together with 70 vol. $\%$ of epoxy matrix to produce 2-ply, 3-ply and 4-ply MWCNT/KF/epoxy laminated composites. The vacuum bagging, curing and post-curing processes were carried out as mentioned previously.

\section{FABRICATION OF MWCNT/WOVEN KENAF/EPOXY} LAMINATED COMPOSITE BY SOLUTION TECHNIQUE

MWCNT/woven kenaf/epoxy laminated composites prepared by solution technique were fabricated as follows; the MWCNT/epoxy suspension was prepared first through sonication of $1.0 \mathrm{vol}$. \% of MWCNT and epoxy in water bath for $20 \mathrm{~min}$ (1 $\mathrm{min}$ on/1 min off) at room temperature to aid dispersion. The suspension was then vacuumed for $60 \mathrm{~min}$ at room temperature to eliminate entrapped air. The curing agent was added to the suspension at a ratio of 100:32 by weight and the suspension was mixed manually for 2 min. After that, an adequate amount of MWCNT/epoxy suspension was spread on the release film surface. The KF fabrics were stacked up together to fabricate 3 different composites having 2-ply, 3-ply and 4-ply KF, followed by hand lay-up and vacuum bagging process. The curing 

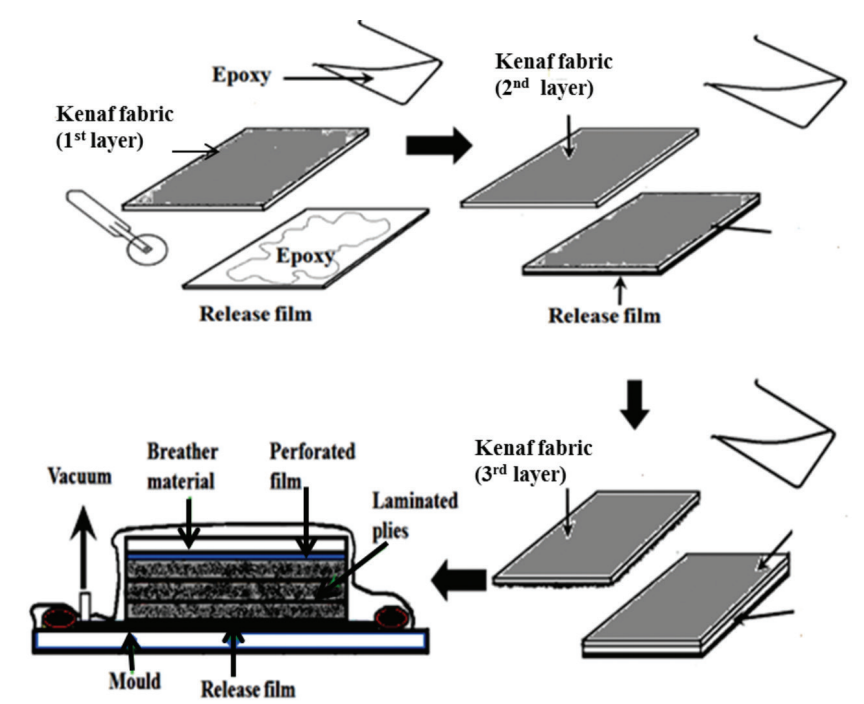

FIGURE 1. The hand lay-up and vacuum bagging procedure performed in the fabrication of $3 \mathrm{KF} /$ epoxy laminated composite

and post-curing processes were carried out as mentioned in previous section.

\section{FABRICATION OF MWCNT/2GF/2KF/EPOXY LAMINATED HYBRID COMPOSITE}

4-ply composite sample containing 2-ply GF as outer layer and 2-ply $\mathrm{KF}$ as middle layer was prepared and denoted as $2 \mathrm{GF} / 2 \mathrm{KF} /$ epoxy laminated hybrid composite. MWCNT was added into the hybrid composite by spraying MWCNT suspension containing $1.0 \mathrm{vol} . \% \mathrm{MWCNT}, 60 \mathrm{~mL}$ deionized water and 5.6 vol. \% Chinese black ink onto the surface of the GF fabrics. This hybrid composite is denoted as MWCNT/2GF/2KF/epoxy laminated composite. These hybrid composites were then compared with $4 \mathrm{GF}$ - and $4 \mathrm{KF}-$ epoxy laminated composite.

\section{CHARACTERIZATIONS}

Flexural test was performed by using INSTRON 5982 aided with Bluehill 2 Software. Rectangular samples with dimension $84 \mathrm{~mm} \times 16 \mathrm{~mm} \times \mathrm{t}$ (with span of $64 \mathrm{~mm}$ ) as shown in Figure 2 were tested according to ASTM D 79010 standard with cross head speed rate at $2 \mathrm{~mm} / \mathrm{min}$. For each case, five specimens were tested and the average values of flexural strength and modulus as well as the specific strength and modulus was calculated and reported in the study. The density of the composite samples was determined by using Micromeritics Pycnometer. Samples of $1 \mathrm{~cm} \times 1 \mathrm{~cm} \times \mathrm{t}$ were prepared for the measurement. Average of 10 readings was calculated. The morphologies of the composites fracture surfaces were observed using an optical microscope.

\section{RESULTS AND DISCUSSION}

Table 1 shows the result of density measurement, flexural strength and flexural modulus for all epoxy laminated

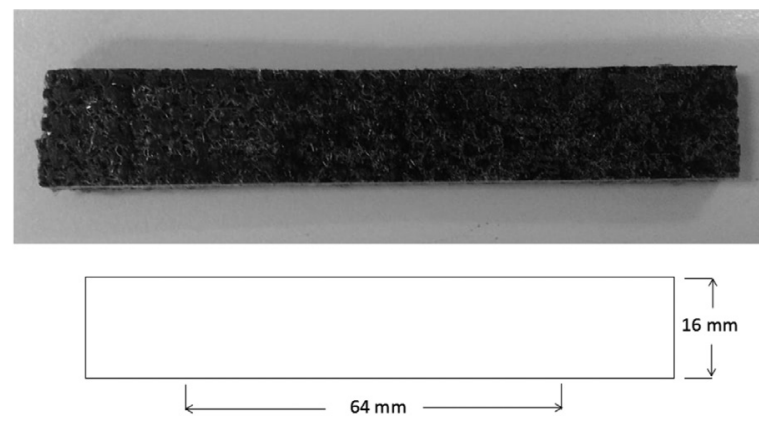

FIGURE 2. Specimen dimension for three-point bending test

composites. As expected, KF/epoxy composites exhibited an increasing density trend with increasing kenaf layer in the composite system. The increment was found marginal from $2 \mathrm{KF}$ to $3 \mathrm{KF}$ but became significant from $3 \mathrm{KF}$ to $4 \mathrm{KF}$. The incorporation of MWCNT into KF/epoxy composite by spraying and solution techniques slightly increased the density of the composite, where the latter exhibited a little bit higher density compared to the former (Dalina 2017). However, in the case of $4 \mathrm{KF}$, the addition of MWCNT was found to reduce the density to the value lower than that of unfilled irrespective of the MWCNT incorporation technique. On the other hand, in the case of hybrid composite $(2 \mathrm{GF} / 2 \mathrm{KF})$, it is observed that density value lied in the middle between the value for $4 \mathrm{GF}$ and $4 \mathrm{KF}$, while the addition of MWCNT into the hybrid composite slightly increased the density value.

Furthermore, from Table 1, it is found that the flexural strength values decreased after the incorporation of MWCNT in KF/epoxy laminated composites. However, a slight improvement in flexural modulus was observed in MWCNT/2KF prepared by solution technique. Comparing between the two techniques, sample prepared by solution technique showed better flexural strength and modulus 
TABLE 1. Density, flexural strength and flexural modulus for KF/epoxy composite, MWCNT/KF/epoxy composite prepared by spraying and solution technique, 4GF/epoxy, and 2GF/2KF/epoxy hybrid composite with and without MWCNT

\begin{tabular}{lccc}
\hline Sample & $\begin{array}{c}\text { Density } \\
\left(\mathrm{g} / \mathrm{cm}^{3}\right)\end{array}$ & $\begin{array}{c}\text { Flexural strength } \\
(\mathrm{MPa})\end{array}$ & $\begin{array}{c}\text { Flexural modulus } \\
(\mathrm{GPa})\end{array}$ \\
\hline 2KF & 1.2643 & 52.67 & 2.02 \\
3KF & 1.2697 & 52.38 & 2.29 \\
4KF & 1.3015 & 59.62 & 2.73 \\
MWCNT/2KF (spray) & 1.2667 & 38.80 & 1.56 \\
MWCNT/3KF (spray) & 1.2749 & 35.59 & 1.27 \\
MWCNT/4KF (spray) & 1.2821 & 39.11 & 2.24 \\
MWCNT/2KF (solution) & 1.2869 & 44.75 & 2.26 \\
MWCNT/3KF (solution) & 1.2962 & 22.20 & 0.65 \\
MWCNT/4KF (solution) & 1.2987 & 50.09 & 2.35 \\
4GF & 2.0308 & 85.35 & 11.3 \\
2GF/2KF & 1.4627 & 66.85 & 5.74 \\
MWCNT/2GF/2KF & 1.4646 & 135.55 & 10.2 \\
\hline
\end{tabular}

than that of spraying technique. The results indicated that the incorporation of MWCNT in KF/epoxy laminated composite did not give significant effect on the flexural properties. Therefore, further investigation was carried out by incorporating MWCNT into glass/kenaf/epoxy hybrid composite (MWCNT/2GF/2KF) which was done by spraying MWCNT suspension on the glass fabrics. Excellent properties were achieved as a result of hybridization where a significant improvement was finally observed in the flexural strength and modulus after the addition of MWCNT. The flexural properties for MWCNT/2GF/2KF are shown in Table 1 together with the values for $4 \mathrm{GF}$ and $2 \mathrm{GF} / 2 \mathrm{KF}$ for comparison.

Similar trend was also observed in the case of specific flexural properties of KF/epoxy composite and MWCNT/ $\mathrm{KF} / \mathrm{epoxy}$ composite prepared by the two techniques as shown in Figures 3 and 4. The specific flexural strength in Figure 2 decreased considerably after the incorporation of MWCNT into the composite system irrespective of the technique used. Solution technique however, showed better specific flexural strength than that of spraying technique. Similarly, the specific flexural modulus in Figure 3 shows a decreasing trend after MWCNT addition except for $2 \mathrm{KF}$

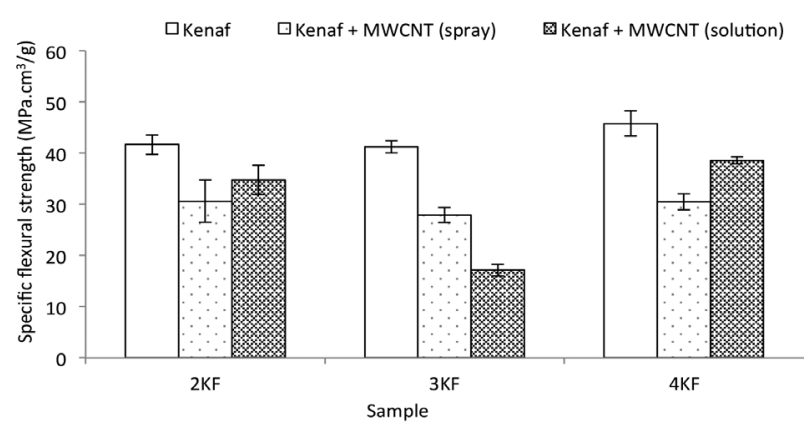

FIGURE 3. Specific flexural strength of unfilled and MWCNT filled $\mathrm{KF} /$ epoxy laminate composite through spraying and solution technique where the addition of MWCNT by solution technique improved the specific modulus value slightly. Possible explanation on the significant reduction of specific flexural properties of MWCNT/KF/epoxy composites could be related to the obvious delamination that occurred between the fibres under compressive load.

To further explain the results, morphology of the fracture surfaces of the composites was observed under optical microscope and 4KF/epoxy composites with and without MWCNT were chosen as representative. As can be observed in Figure 5(a), it can be seen that the composite failure was due to the fracture that occurred at the bottom layer of the composite which might then followed by delamination at the middle of the kenaf layers. This signifies the higher flexural strength and modulus of 4KF/epoxy composite compared to others. Meanwhile, morphology in Figure 5(b) and 5(c) which is for MWCNT/4KF (spray) and MWCNT/4KF (solution), respectively, shows clear, deep fault lines developed between ply layers, indicating the debonding and delamination mechanisms without significant occurrence of buckling.

The effect of glass-kenaf hybridization on the flexural properties and specific flexural properties of epoxy

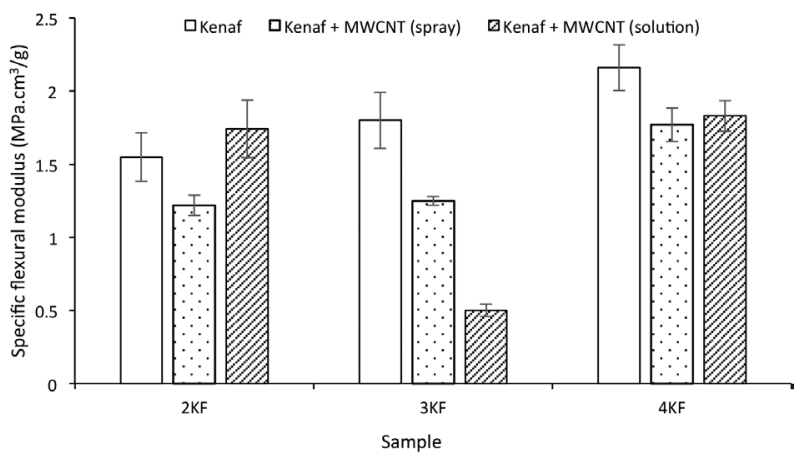

FIGURE 4. Specific flexural modulus of unfilled and MWCNT filled $\mathrm{KF} /$ epoxy laminate composite through spraying and solution technique 


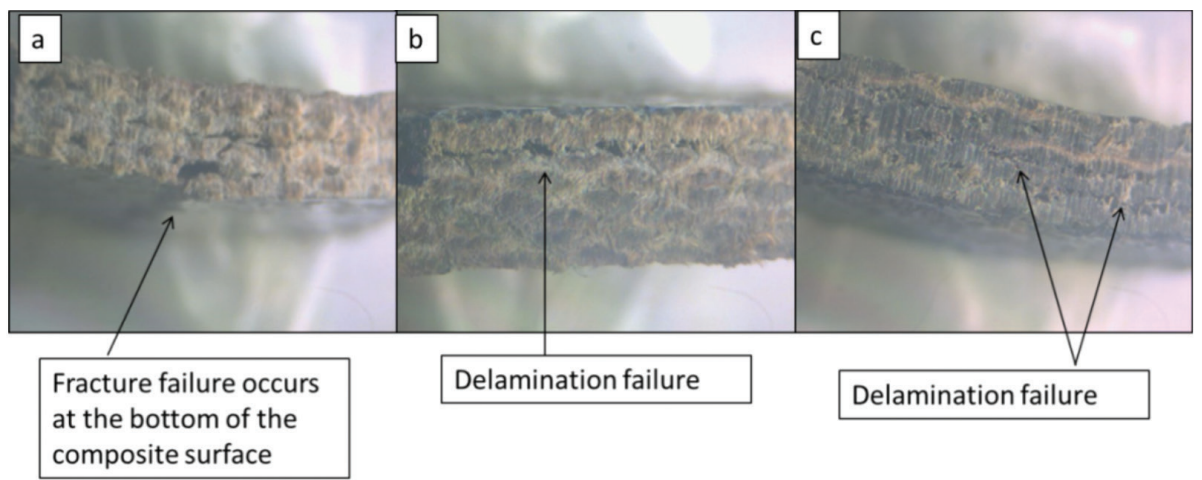

FIGURE 5. Morphology of cross sectional area of (a) 4KF, (b) CNT/4KF (spray), and (c) MWCNT/4KF (solution) reinforced epoxy laminated composites

laminated composites can be seen in Figures 6 and 7, respectively. The flexural strength and modulus of hybrid composite was found higher than the composite with single kenaf reinforcement $(4 \mathrm{KF})$. The flexural properties of $4 \mathrm{KF} /$ epoxy composite were somewhat lower because of less stiff and typically low brittle of kenaf fibre. Reinforcing the composite through hybridization with glass fibre therefore improved its flexural strength and flexural modulus. However, in the case of specific flexural strength, the values were found marginal as comparison is made between the three composite samples ( $4 \mathrm{KF}, 4 \mathrm{GF}$ and $2 \mathrm{GF} / 2 \mathrm{KF}$ ). On the other hand, the specific flexural modulus was higher in

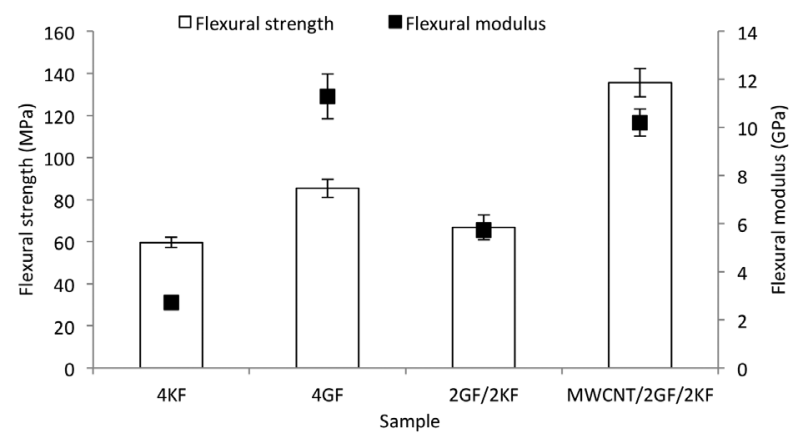

FIGURE 6. Flexural strength (bar graph) and flexural modulus (scatter plot) of $4 \mathrm{KF}, 4 \mathrm{GF}, 2 \mathrm{GF} / 2 \mathrm{KF}$ and $\mathrm{MWCNT} / 2 \mathrm{GF} / 2 \mathrm{KF}$ epoxy laminated composite

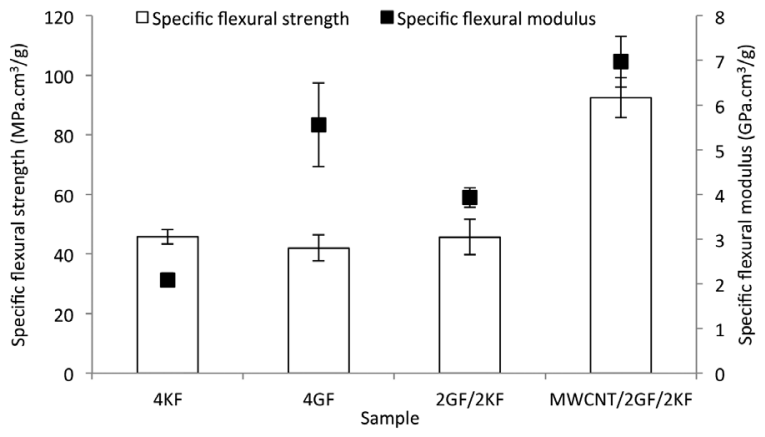

FIGURE 7. Specific flexural strength (bar graph) and specific flexural modulus (scatter plot) of 4KF, 4GF, $2 \mathrm{GF} / 2 \mathrm{KF}$ and $\mathrm{MWCNT} / 2 \mathrm{GF} / 2 \mathrm{KF}$ epoxy laminated composite hybrid composite compared to that of $4 \mathrm{KF}$, indicating the significant effect of hybridization in term of composite stiffness.

Furthermore, it is interesting to note that the incorporation of $1.0 \mathrm{vol} \%$ of MWCNT into hybrid composite caused a significant increase in both flexural and specific flexural properties of the composite. The flexural strength and specific flexural strength of the hybrid composite showed an improvement from 66.85 to $135.55 \mathrm{MPa}$ and 45.80 to $92.55 \mathrm{MPa}$, respectively, after the addition of MWCNT. The magnitude of increment was about 2 times greater than the values observed for the unfilled hybrid composite. It should be reiterated here that the incorporation of MWCNT was done by spraying MWCNT onto the glass fibre. The presence of MWCNT provided a good interaction between glass-epoxy-kenaf which promoted the load transfer between them (Li et al. 2015). The result can be supported by observing morphology of MWCNT/2GF/2KF in Figure 8. The morphology showed that no significant delamination occurred between glasskenaf layers, proving the good interaction between them. However, the delamination can be clearly observed at kenaf-kenaf layers in the composite system.

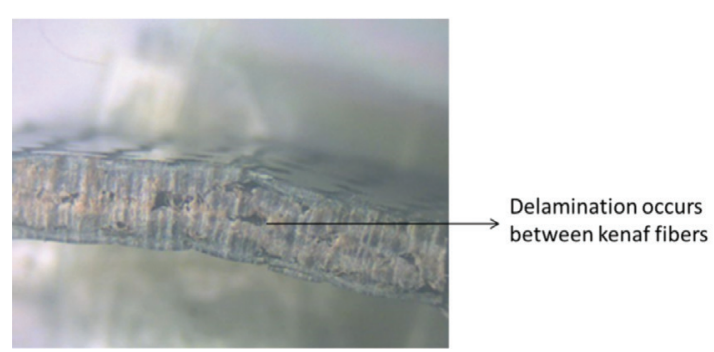

FIGURE 8. Microstructure of fracture surface of MWCNT/2GF/2KF/epoxy laminated composite

The incorporation of MWCNT was also found to remarkably increase the flexural modulus and specific flexural modulus of the hybrid composite. The mechanism of improving flexural properties through the addition of MWCNT in hybrid composite can be analyzed as follows: 
MWCNT possess ultrahigh strength and modulus, and it is likely that the presence of MWCNT in the $2 \mathrm{GF} / 2 \mathrm{KF} /$ epoxy composites effectively strengthened and stiffened the GF and promoted interaction between GF-epoxy-kenaf (Li et al. 2015).

Figure 9 shows the flexural stress-strain curves for 4KF, 4GF, 2GF/2KF and MWCNT/2GF/2KF epoxy laminated composites. It is obvious that the composites showed different trends during deformation under compressive load. 4KF and 4GF showed different failure behaviour which believed to be respectively related to the intrinsic properties of kenaf and glass fibre. Based on the curves, 4GF showed no elongation with higher break load, indicating that the composites were much more rigid and stronger compared to $4 \mathrm{KF}$. Interestingly, it appears that the hybridization of kenaf and glass $(2 \mathrm{GF} / 2 \mathrm{KF})$ caused the composites to elongate more (up to $14 \%$ ) before reaching the composite failure, though the enhancement in the break load of the hybrid composite was insignificant. This resembles that the hybrid composite withstands more strain than the single fibre composite before failure. Ramnath et al. (2013) reported similar observation on increasing ductility of epoxy composite reinforced with hybrid abaca-jute-glass.

Furthermore, the break load increased considerably after MWCNT addition in the hybrid composite, which however, accompanied by an abrupt decrease in failure strain. This indicated the presence of MWCNT increased the brittleness of the composite. Obviously, it is noticed that the hybrid composite showed two failure modes. After the maximum flexural load point which is assumed to be due to the breakage of the first layer (MWCNT/ glass layer), the graph decreased and showed haphazard behaviour which could be due to kenaf fibres that tend to pull out from the composite at the breaking point. This led to random increase and decrease of curve in graph before it finally broke (Ramnath et al. 2013).

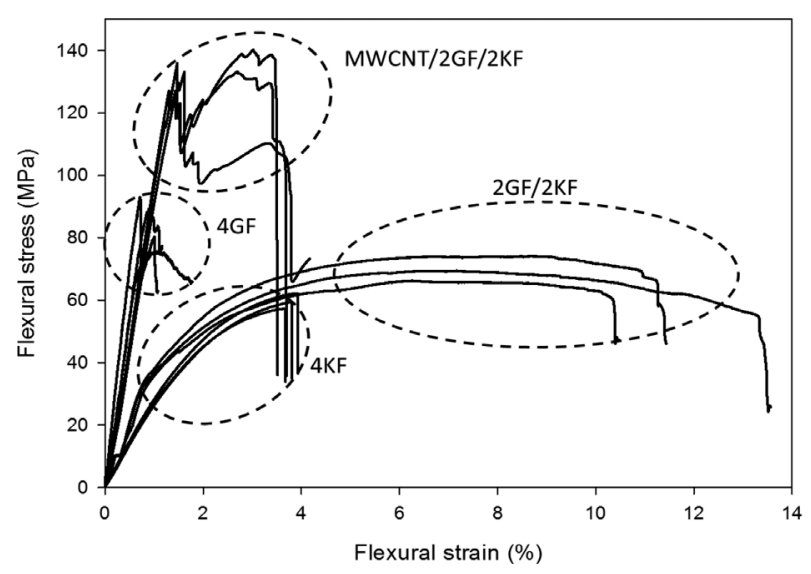

FIGURE 9. Flexural stress-strain curves of 4KF, 4GF, 2GF/2KF and MWCNT/2GF/2KF epoxy laminated composite

\section{CONCLUSION}

In this study, the flexural properties of MWCNT/woven kenaf/epoxy laminated composite and MWCNT/woven glass/woven kenaf/epoxy hybrid composite were evaluated. The incorporation of 1 vol\% of MWCNT into woven kenaf/ epoxy laminated composites using spraying and solution technique was found to decrease the flexural properties of the composites. Comparing between spraying and solution technique, the latter technique resulted in better flexural properties than the former. The decreasing flexural trend was due to delamination failure. On the other hand, since the addition of MWCNT into woven kenaf/epoxy composites negatively impact their flexural properties, further investigation was carried to incorporate MWCNT into woven glass/woven kenaf/epoxy hybrid composite by spraying MWCNT on the woven glass fibres. From the results, significant improvement in both flexural and specific flexural properties has been achieved in MWCNT/woven glass/woven kenaf/epoxy hybrid composite compared to that of unfilled hybrid composite and the results were even higher than that of 4-ply woven glass/epoxy composite especially in the specific flexural properties. Thus, it can be concluded that MWCNT showed good interaction with woven glass leading to improved flexural properties of woven glass/ woven kenaf/epoxy hybrid composite but negatively impact the properties of woven kenaf irrespective of incorporation technique leading to reduced flexural properties of woven kenaf/epoxy composites.

\section{ACKNOWLEDGEMENTS}

The authors would like to thank Universiti Sains Malaysia for Postdoctoral Research Scheme and Cluster for Polymer Composites (CPC) for the contribution to this project.

\section{REFERENCES}

Dittenber, D.B. \& Gangarao, H.V. 2012. Critical review of recent publications on use of natural composites in infrastructure. Composites Part A: Applied Science \& Manufacturing 43(8): 1419-1429.

Krishna, K.V. \& Kanny, K. 2016. The effect of treatment on kenaf fibre using green approach and their reinforced epoxy composites. Composites Part B: Engineering 104: 111-117.

Li, X., Tabil, L.G. \& Panigrahi, S. 2007. Chemical treatments of natural fibre for use in natural fibre-reinforced composites: A review. Journal of Polymers \& the Environment 15(1): 25-33.

Li, Y., Chen, C., Xu, J., Zhang, Z., Yuan, B. \& Huang, X. 2015. Improved mechanical properties of carbon nanotubes-coated flax fibre reinforced composites. Journal of Materials Science 50(3): 1117-1128.

Maslinda, A.B., Majid, M.A., Ridzuan, M.J.M., Afendi, M. \& Gibson, A.G. 2017. Effect of water absorption on the mechanical properties of hybrid interwoven cellulosiccellulosic fibre reinforced epoxy composites. Composite Structures 167: 227-237.

Ramnath, B.V., Kokan, S.J., Raja, R.N., Sathyanarayanan, R., Elanchezhian, C., Prasad, A.R. \& Manickavasagam, V.M. 2013. Evaluation of mechanical properties of abaca-jute- 
glass fibre reinforced epoxy composite. Materials \& Design 51: 357-366.

Wan Dalina, W.A.D. 2017. Glass fibre/carbon nanotubes/ epoxy composites. PhD Thesis. Universiti Sains Malaysia (Unpublished).

Yusriah, L., Mariatti, M. \& Abu Bakar, A. 2010. Mechanical properties of particulate-filler/woven-glass-fabric-filled vinyl ester composites. Journal of Vinyl \& Additive Technology 16(1): 98-104.

School of Materials and Mineral Resources Engineering Engineering Campus

Universiti Sains Malaysia

14300 Nibong Tebal, Pulau Pinang

Malaysia
*Corresponding author; email: mariatti@usm.my

Received: 16 May 2017

Accepted: 19 September 2017 